\title{
Interannual variations of shallow firn temperature at Greenland summit
}

\author{
LI Jun, ${ }^{1}$ WeILI WANG, ${ }^{1}$ H. JAY ZWALLY ${ }^{2}$ \\ ${ }^{1}$ Raytheon ITSS, NASA Goddard Space Flight Center, Code 971, Greenbelt, MD 20771, U.S.A. \\ E-mail: lijun@icesat2.gsfc.nasa.gov \\ ${ }^{2}$ Oceans and Ice Branch, NASA Goddard Space Flight Center, Code 971, Greenbelt, MD 20771, U.S.A.
}

\begin{abstract}
Firn-temperature profiles are calculated in a thermal model using continuous surface temperatures derived from automatic weather station data and passivemicrowave data in the Greenland summit region during the period 1987-99. The results show that significant interannual variations of mean summer (June-August) and annual temperatures occur in the top $15 \mathrm{~m}$, in addition to the normal seasonal cycle of firn temperature. At $5 \mathrm{~m}$ depth, the seasonal cycle is damped to $13 \%$ of the surface seasonal range, but even at $15 \mathrm{~m}$ about $1 \%$ or $0.6^{\circ} \mathrm{C}$ of the seasonal cycle persists. Both summer and mean annual temperatures decrease from 1987 to 1992, followed by a general increasing trend. Interannual variability is $5^{\circ} \mathrm{C}$ at the surface, but is dampened to $3.2^{\circ} \mathrm{C}$ at $5 \mathrm{~m}$ depth and $0.7^{\circ} \mathrm{C}$ at $15 \mathrm{~m}$ depth. Dampening of the interannual variability with depth is slower than dampening of the seasonal cycle, because of the longer time constant of the interannual variation. The warmer spring and summer temperatures experienced in the top $5 \mathrm{~m}$, due to both the seasonal cycle and interannual variations, affect the rate of firn densification, which is nonlinearly dependent on temperature. During the 12 year period $1987-99$, the annual mean surface temperature is $-29.2^{\circ} \mathrm{C}$, and the annual mean $15 \mathrm{~m}$ temperature is $-30.1^{\circ} \mathrm{C}$, which is $>1{ }^{\circ} \mathrm{C}$ warmer than a $15 \mathrm{~m}$ borehole temperature representing the period around 1959 and warmer than the best-fit temperature history by Alley and Koci (1990) back to AD 1500.
\end{abstract}

\section{INTRODUGTION}

Snow surface temperature and near-surface air temperatures on polar ice sheets show pronounced seasonal cycles and significant interannual variations. These short-term variations are significantly dampened with depth, while decadal and longer temporal variations are maintained as a climatic record of temperature. For example, previous analysis of the temperature--depth variation at Summit, Greenland, showed a minimum temperature of $-31.5^{\circ} \mathrm{C}$ at $130 \mathrm{~m}$, corresponding to about AD 1659 (Alley and Koci, 1990). Seasonal and interannual variations in firn temperature also drive changes in the rate of firn densification, which causes changes in the snow surface, as detected by satellite radar altimeter $(\mathrm{Li}$ and Zwally, 2002; Zwally and Li, 2002). In this paper, we use the continuous surface temperature record compiled from automatic weather station (AWS) and passive-microwave data by Shuman and others (2001) for the Summit region over the period 1987-99 to derive the corresponding firn-temperature evolutions with depth.

\section{THE MODEL}

We follow the standard time-dependent heat-transfer equation (cf. Paterson 1994, p. 224), which in one dimension can be written:

$$
\rho c \frac{\partial T}{\partial t}=K \nabla^{2} T+\left(\frac{\mathrm{d} K}{\mathrm{~d} z}-\rho c w\right) \frac{\partial T}{\partial z}+f,
$$

where $\partial T / \partial t$ is the change in firn temperature $T$ with time $t$ at depth $z, \rho$ is density, $c$ is heat capacity of ice, $K$ is thermal conductivity, $w$ is vertical velocity and $f$ is internal heating. Thermal properties of ice and firn used in the model are computed from the relations given by Paterson (1994, p. 205). Thermal conductivity $(K)$ for firn as a function of the density is calculated using Schwerdtfeger's (1963) equation:

$$
K=\frac{2 K_{\mathrm{i}} \rho}{\left(3 \rho_{\mathrm{i}}-\rho\right)},
$$

where $K_{\mathrm{i}}$ is thermal conductivity of ice and $\rho_{i}$ is the density of ice $\left(917 \mathrm{~kg} \mathrm{~m}^{-3}\right)$. We use Schytt's (1958) empirical densitydepth relation adjusted according to field density measurements to calculate variations of firn density with depth:

$$
\rho(z)=\rho_{\mathrm{i}}-\left(\rho_{\mathrm{i}}-\rho_{\mathrm{s}}\right) \exp (-C z) .
$$

In Equation (3), $\rho(z)$ is firn density at depth $z, \rho_{\mathrm{s}}$ is the density of surface snow $\left(350 \mathrm{~kg} \mathrm{~m}^{-3}\right)$ and the constant $C$ is taken as $0.029 \mathrm{~m}^{-1}$ to give the best fit to the available field data collected in the Summit region (Gow and others, 1997; Hamilton and Whillans, 2000).

Vertical velocity $(w)$ is calculated according to the Dansgaard and Johnsen (1969) model by using a constant accumulation rate of $250 \mathrm{~kg} \mathrm{~m}^{-2} \mathrm{a}^{-1}$ (Zwally and Li, 2002). Internal heating $(f)$ is neglected in this analysis by assuming that $f$ is smaller than the coefficients of $\partial T / \partial t$ by at least three orders of magnitude (Van Ommen and others, 1999).

To solve Equation (1) two boundary conditions are needed: the upper boundary (the driving temperature), the temperatures at the snow surface; and the lower boundary (at which the temperature is considered to be constant), a known temperature at a certain depth. Figure 1 shows the driving surface temperature used in this study. This time 


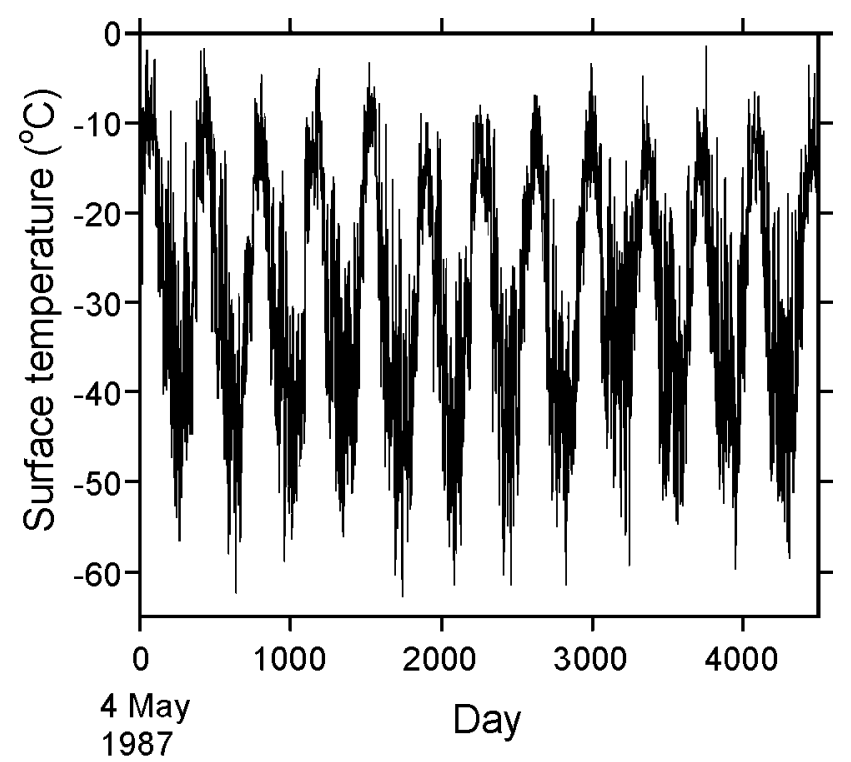

Fig. 1. Daily variations of surface air temperature for Summit, May 1987-October 1999 (after Shuman and others, 2001).

series of the temperature over the period 1987-99 was derived from AWS and passive-microwave data for the Summit region (Shuman and others, 2001). For the lower boundary, we chose the measured Greenland Ice Sheet Project 2 (GISP2) borehole temperature at $30 \mathrm{~m}$ depth $\left(-31.4^{\circ} \mathrm{C}\right.$; Alley and Koci, 1990). This depth choice is sufficient to avoid any effect of penetration of the surface temperature wave during the 12 years on the lower boundary condition, as confirmed by several numerical tests.

\section{RESULTS AND DISGUSSION}

The surface driving temperature for the Summit region over the period 1987-99, on a daily basis, is shown in Figure 1. The temperature fluctuates within the maximum range between approximately $-60^{\circ}$ and close to $0^{\circ} \mathrm{C}$, exhibiting clear annual cycles with an average range of about $55^{\circ} \mathrm{C}$. A distinct cooling period occurs in 1992. In this period the mean annual temperature $\left(T_{\mathrm{m}}\right)$ and mean summer temperature (1 June-3l August) is $>4^{\circ} \mathrm{C}$ lower than the average. $T_{\mathrm{m}}$ is averaged from 1 September to 31 August of the following year. The temperature decreases from 1987, reaching a minimum in 1992, and then gradually increases until 1999. The cooler temperatures in 1992 in Greenland have been attributed to a cooling associated with the Mount Pinatubo (Philippines) eruption (Abdalati and Steffen, 1997). The mean annual temperature and summer temperature

Table 1. Dampening of ranges of seasonal variations in temperature and interannual variations (1987-99) in temperature with depth

\begin{tabular}{lccccccccccc}
\hline & $0 m$ & $1 m$ & $2 m$ & $3 m$ & $\begin{array}{c}\text { Depth } \\
4 m\end{array}$ & $5 m$ & $7 m$ & $10 m$ & $15 m$ \\
\hline $\begin{array}{c}\text { Seasonal } \\
\text { range }\left({ }^{\circ} \mathrm{C}\right)\end{array}$ & 55.16 & 27.71 & 18.58 & 13.59 & 9.95 & 7.26 & 3.95 & 1.66 & 0.61 \\
$\begin{array}{c}\text { Interannual } \\
\text { range }\left({ }^{\circ} \mathrm{C}\right)\end{array}$ & 4.95 & 4.28 & 3.82 & 3.70 & 3.50 & 3.24 & 2.61 & 1.55 & 0.73 \\
\hline
\end{tabular}

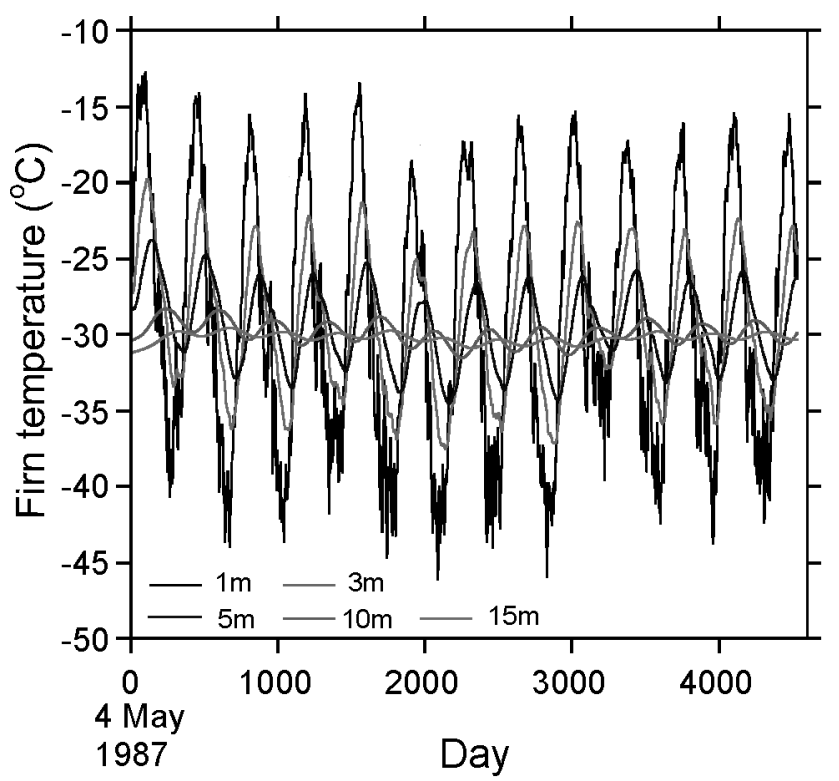

Fig. 2. Variations of firn temperature computed at several depths above 15 m for Summit, May 1987-October 1999.

averaged from 1987 to 1991 approximately are $-28.4^{\circ}$ and $-12.8^{\circ} \mathrm{C}$, compared with $-29.3^{\circ}$ and $-15.0^{\circ} \mathrm{C}$ for $1993-99$.

Driven by this surface temperature variation, Figure 2 illustrates the modeled firn-temperature changes at several selected depths over the corresponding period. At $3 \mathrm{~m}$ depth, the range of the firn temperature is attenuated to $25 \%$ of the surface value. As expected, the range of the seasonal variation significantly reduces with depth from $27.7^{\circ} \mathrm{C}$ at $1 \mathrm{~m}$ to $0.61^{\circ} \mathrm{C}$ at $15 \mathrm{~m}$ (Table 1). Nevertheless, the residual ranges of $1.66^{\circ} \mathrm{C}$ at $10 \mathrm{~m}$, and $0.61^{\circ} \mathrm{C}$ at $15 \mathrm{~m}$, indicate that significant corrections to measured borehole temperatures at these depths are required to obtain the mean annual surface temperature. Over the period 1987-99, the annual

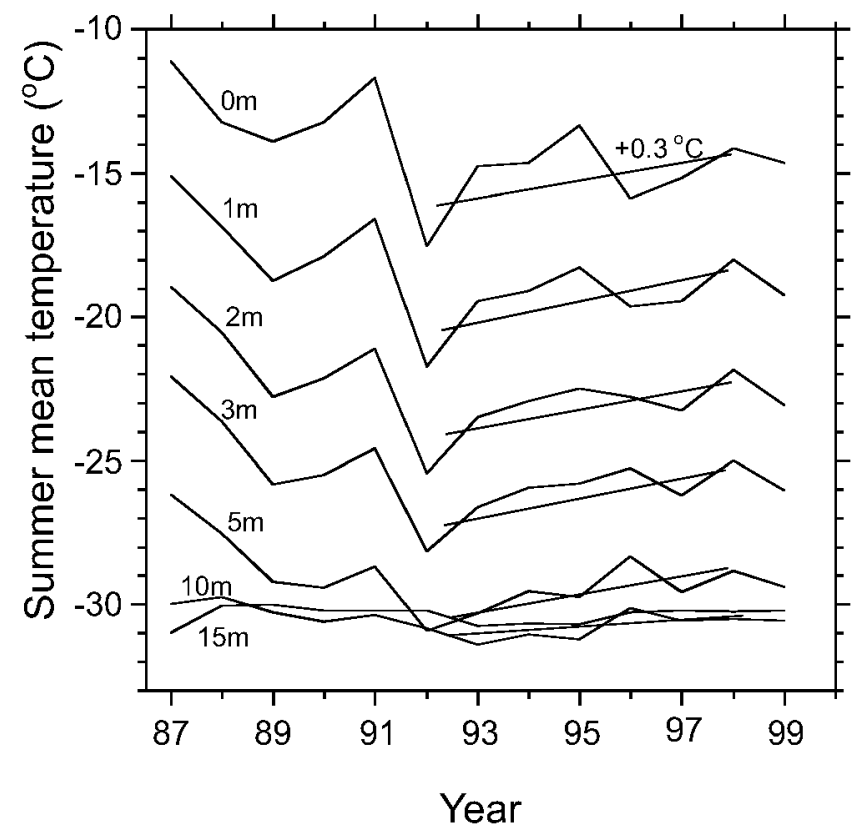

Fig. 3. Interannual variations of summer mean firn temperatures (Fune-August) at several depths above $15 \mathrm{~m}$ at Summit, May 1992-October 1999. Fitted lines at each depth show 1992-99 warming trend with $+0.3^{\circ} \mathrm{Ca}^{-1}$ at the surface. 


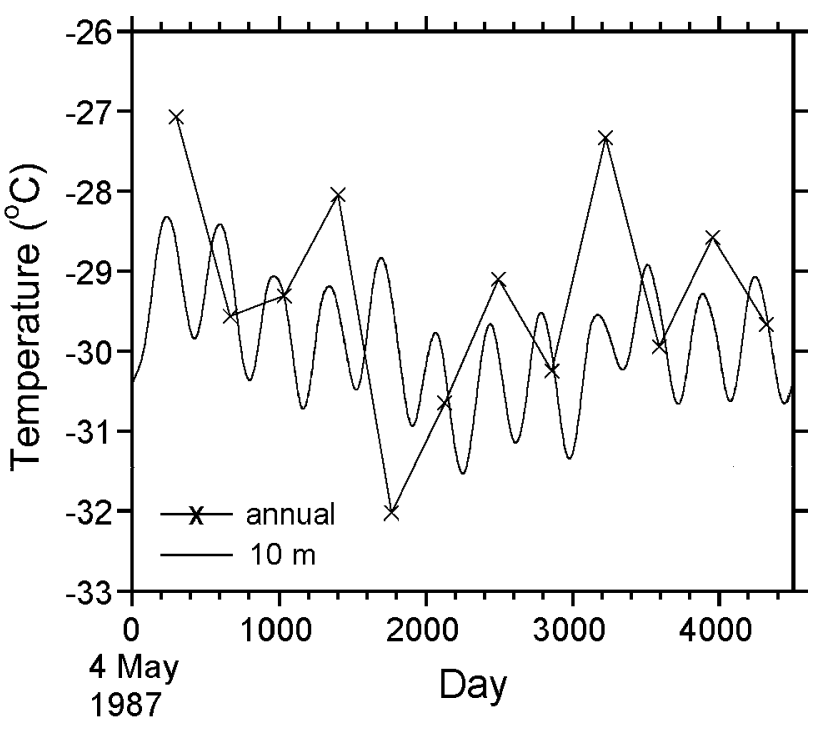

Fig. 4. Comparison between modeled $10 \mathrm{~m}$ firn temperature and mean annual surface air temperature at Summit, showing interannual variations during May 1987- October 1999.

mean surface temperature is $-29.3^{\circ} \mathrm{C}$. At lower depths the means are $-29.9^{\circ} \mathrm{C}$ at $10 \mathrm{~m},-30.1^{\circ} \mathrm{C}$ at $15 \mathrm{~m}$, and $-31.4^{\circ} \mathrm{C}$ at $30 \mathrm{~m}$, which approaches the fixed and colder lower-boundary condition obtained from the borehole measurement.

Interannual changes of mean summer firn temperature at several depths are shown in Figure 3, together with the values from the surface temperature. The summer temperatures are important in firn densification, which has been found to be a dominant factor in the seasonal surface elevation change (Zwally and Li, 2002). From 1992 to 1999, a clear warming trend with a rate of approximately $+0.3^{\circ} \mathrm{Ca}^{-1}$ is indicated by each regression line through the data for the top $5 \mathrm{~m}$ of firn. The results show that the interannual variations of the surface summer temperature are large above $5 \mathrm{~m}$ and significantly damped below $10 \mathrm{~m}$.

Table 1 shows that the range of the interannual variations in $T_{\mathrm{m}}$ at $5 \mathrm{~m}$ depth is about $65 \%$ of the range at the surface, and is damped approximately linearly with depth to about $30 \%$ at $10 \mathrm{~m}$ and $15 \%$ at $15 \mathrm{~m}$. In contrast, above $5 \mathrm{~m}$ the damping of the seasonal variations with depth is much faster than the damping of interannual variations.

Figure 4 shows the modeled firn temperature at $10 \mathrm{~m}$ depth (solid line) together with mean annual surface temperature $T_{\mathrm{m}}$. Although the variation is small $\left(<2^{\circ} \mathrm{C}\right)$, both sets of data still show that the temperature dropped about $2{ }^{\circ} \mathrm{C}$ from 1987 to 1992 followed by a general warming trend. The clear seasonal variation shown by the solid line and the discrepancy between the two sets of data seems to indicate that $10 \mathrm{~m}$ temperature is significantly affected by both the seasonal cycle and interannual variations in temperature.

The $T_{\mathrm{m}}$ for all 12 years except $1992\left(T_{\mathrm{m}}=-32.0^{\circ} \mathrm{C}\right)$ is warmer than the maximum temperature of $-31.25^{\circ} \mathrm{C}$ measured at $15 \mathrm{~m}$ depth in the 1989 borehole (Alley and Koci, 1990). In 1989, a depth of $15 \mathrm{~m}$ corresponded to a time about 30 years prior to the drilling, or about 1959 . While the meas- ured borehole temperatures ranged from the $-31.5^{\circ} \mathrm{C}$ minimum measured at $130 \mathrm{~m}$ depth to the $-31.25^{\circ} \mathrm{C}$ measured at $15 \mathrm{~m}$ (a difference of $0.25^{\circ} \mathrm{C}$ ), the range in the best-fit surface temperature history is larger at about $2^{\circ} \mathrm{C}$ (Alley and Koci, 1990). From their temperature reconstruction, Alley and Koci (1990) concluded that the indicated warming falls within the range of natural variability and provides no clear evidence of a greenhouse signal. During the 12 year period 1987-99, however, the mean annual surface temperature is $-29.2^{\circ} \mathrm{C}$, and the mean annual $15 \mathrm{~m}$ temperature is $-30.1^{\circ} \mathrm{C}$, which is $>1{ }^{\circ} \mathrm{C}$ warmer than a $15 \mathrm{~m}$ borehole temperature representing the period around 1959 and warmer than the best-fit temperature history by Alley and Koci (1990) back to AD 1500. Even though the middle of the 1987-99 period was affected by the atmospheric cooling effects of the Mount Pinatubo volcanic eruption, the period was on average warmer by at least $1^{\circ} \mathrm{C}$ than recent century-scale average temperatures.

The continuous temperature data shown by Figure 1 provide the most detailed and complete near-surface temperature record for the Summit region during the period 1987-99. Therefore, they are especially useful in the analysis of surface elevation data retrieved from satellite radar altimeter (European Remote-sensing Satellites 1 and 2) for the period 1992-99. This temperature record is assumed to be the snow temperature at the surface in the present analysis. More precise calibration using some of the field firn-temperature measurements made during this period should be undertaken to ensure the modeled firn temperatures with depth are in agreement with field data.

\section{REFERENGES}

Abdalati, W. and K. Steffen. 1997. Snowmelt on the Greenland ice sheet as derived from passive microwave satellite data. 7. Climate, 10 (2), 165-175.

Alley, R. B. and B. R. Koci. 1990. Recent warming in central Greenland? Ann. Glaciol., 14, 6-8.

Dansgaard,W. and S. J. Johnsen. 1969. A flow model and a time scale for the ice core from Camp Century, Greenland. F. Glaciol., 8(53), 215-223.

Gow, A. J. and 6 others. 1997. Physical and structural properties of the Greenland Ice Sheet Project 2 ice cores: a review. f. Geophys. Res., 102(C12), 26,559-26,575.

Hamilton, G. S. and I. M. Whillans. 2000. Point measurements of mass balance of the Greenland ice sheet using precision vertical global positioning system (GPS) surveys. 7. Geophys. Res., 105(B7), 16,295-16,301.

Li Jun and H. J. Zwally. 2002. Modeled seasonal variations of firn density induced by steady-state surface air-temperature cycle. Ann. Glaciol., 34, 299-302.

Paterson, W. S. B. 1994. The physics of glaciers. Third edition. Oxford, etc., Elsevier.

Schwerdtfeger, P. 1963. Theoretical derivation of the thermal conductivity and diffusivity of snow. International Association of Scientific Hydrology Publication 61 (General Assembly of Berkeley 1963 - Snow and Ice), 75-81.

Schytt, V. 1958. Glaciology II $(\mathrm{C})$. The inner structure of the ice shelf at Maudheim as shown by core drilling. Norwegian-British-Swedish Antarctic Expedition, 1949-52. Sci. Results IV, 113-151.

Shuman, C. A., K. Steffen, J. E. Box and C. R. Stearns. 2001. A dozen year of temperature observations at the Summit: central Greenland automatic weather stations 1987-1999. 7. Appl. Meteorol., 40(4), 741-752.

Van Ommen, T. D., V. I. Morgan, T. H. Jacka, S. Woon and A. Elcheikh. 1999. Near-surface temperatures in the Dome Summit South (Law Dome, East Antarctica) borehole. Ann. Glaciol., 29, 141-144.

Zwally, H.J. and Li Jun. 2002. Seasonal and interannual variations of firn densification and ice sheet surface elevation at the Summit of Greenland. F. Glaciol., 48(161), 199-207 